\title{
Р.Ю. Кравченко
}

Комунальне некомерційне підприємство «Чернігівська обласна лікарня» Чернігівської обласної ради, Чернігів, Україна

\section{Новоутворення середостіння. Помилки в діагностиці та їх вирішення}

Анотація. Пухлини середостіння - рідкісна патологія, складність виявлення якої обумовлена відсутністю специфічних симптомів і можливістю тривалого безсимптомного перебігу. У статті представлені клінічна картина, діагностика, класифікація та підходи до лікування при епітеліальних пухлинах вилочкової залози. Зазначено, що хірургічне лікування відіграє важливу роль у лікуванні та правильній діагностиці новоутворень середостіння, особливо злоякісних. Використання мініінвазивних методів діагностики (відеоторакоскопія, трансторакальна голкова біопсія) дозволяє отримати морфологічну верифікацію при підготовці до лікування й обрати найбільш безпечний і оптимальний вид лікування. Описано переваги внутрішньоартеріального введення хіміопрепаратів. Наведено клінічний випадок обстеження та лікування тяжкого пацієнта з пухлиною заднього середостіння та наявністю супутньої патології. Ключові слова: пухлини вилочкової залози, епітеліальні пухлини тимуса, тимома, карцинома тимуса.

\section{Вступ}

Вперше новоутворення вилочкової залози описано J. Lantensau та G. Kay у 1867 р., а термін «тимома» запропонований F. Grandhomme у 1900 р. для визначення всіх пухлин цього органа [1].

Епітеліальні пухлини тимуса включають тимому і карциному. Тимома - найпоширеніша первинна пухлина в передньому середостінні, але взагалі відмічається рідко $(1,5$ випадку на 1 млн). Хоча тимома може поширюватися локально, вона набагато менш інвазивна, ніж карцинома тимусу. Пацієнти з карциномами тимусу часто мають метастази. 5-річна виживаність пацієнтів із тимомами досягає $90 \%$, тоді як при карциномі тимусу цей показник становить близько 55\% [2].

\section{Клінічна картина}

Клінічні прояви залежать від розмірів пухлини, ендокринної активності, характеру росту з подальшою компресією суміжних структур. Неінвазивні тимоми здебільшого мають безсимптомний перебіг. Злоякісний характер тимоми визначається її інвазивністю та метастазуванням, що зумовлює збільшення вираженості клінічних проявів, та подальшим прогнозом. 10-40\% тимом поєднуються 3 паранеопластичними синдромами. Можуть розвинутися інтоксикація, анемія, а при стисненні верхньої порожнистої вени розвиваються ціанотичність обличчя, набряк верхнього плечового поясу, головний біль, порушення показників гемодинаміки.

\section{Діагностика}

Основний метод діагностики при будь-якій онкологічній патології - морфологічна верифікація. Головне - визначити інкапсульовану або інвазивну форму хвороби.

Основний метод променевої діагностики - мультиспіральна комп'ютерна томографія (МСКТ) органів грудної клітки (ОГК) 3 внутрішньовенним контрастуванням та магнітно-резонансна томографія. Для отримання цитологічного матеріалу можна використовувати трансторакальну пункцію під контролем МСКТ. Серед більш інвазивних методів - медіастиноскопія і парастернальна медіастинотомія.

Лабораторна діагностика включає патогістологічне дослідження матеріалу, але, враховуючи, що цей метод не завжди дозволяє встановити походження пухлини, найбільш ефективним $\epsilon$ метод імуногістохімічного дослідження, що дозволяє визначити злоякісну трансформацію пухлини.

Одні з допоміжних методів діагностики при інвазивних пухлинах середостіння - фіброезофагоскопія (ФЕС) та фібробронхоскопія, що дозволяє визначити ступінь інвазії в структури середостіння, якщо вони $\epsilon$, та при можливості взяти біопсію для цитологічного дослідження [3].

\section{Класифікація}

A. Masaoka у 1981 р. запропоновано класифікацію із стадіювання, яку застосовують дотепер:

І стадія $\left(\mathrm{T}_{1} \mathrm{~N}_{0} \mathrm{M}_{0}\right)$ - повністю інкапсульована пухлина без інвазії в медіастинальну клітковину;

II стадія $\left(\mathrm{T}_{2} \mathrm{~N}_{0} \mathrm{M}_{0}\right)$ - інфільтрація пухлини в межах жирової клітковини;

III стадія $\left(\mathrm{T}_{3} \mathrm{~N}_{0} \mathrm{M}_{0}\right)$ - інфільтрація медіастинальної плеври, перикарда або прилеглих органів:
а) відсутність інвазії великих судин;
b) інвазія великих судин;
IV стадія:
a) пухлина з імплантацією в плевру і перикард $\left(\mathrm{T}_{4} \mathrm{~N}_{0} \mathrm{M}_{0}\right)$;
b) пухлина з лімфогенними метастазами $\left(\mathrm{T}_{1-4} \mathrm{~N}_{1-2} \mathrm{M}_{0}\right)$;
c) пухлина з гематогенними метастазами $\left(\mathrm{T}_{1-4} \mathrm{~N}_{0-2} \mathrm{M}_{1}\right)[4,5]$.

\section{Лікування}

Хірургічне лікування як самостійний метод може застосовуватися тільки при I, рідше - II стадії пухлини тимуса, тобто при інкапсульованих і малоінвазивних пухлинах. В усіх інших випадках пацієнти підлягають комбінованому, комплексному або консервативному лікуванню. При комбінованому і комплексному лікуванні перевагу слід надавати неоад'ювантним методам, що дозволяє досягти регресії пухлини, зменшити ії обсяг, обмежити інвазію навколишніх тканин, а також перевести неоперабельний процес в операбельний.

Ендоваскулярні технології, а саме регіонарна хіміотерапія в передопераційний період як підготовчий етап, підвищують рівень абластики та антибластики при хірургічному лікуванні тимом і знижують вплив цитостатиків на організм, як при внутрішньовенному введенні, у хворих із паранеопластичним синдромом збільшують термін регресії його проявів [6].

Внутрішньоартеріальне введення хіміопрепаратів має певні переваги:

- цитостатики по артеріях, які кровопостачають пухлину, вводять безпосередньо в зону ураження, що дозволяє суттєво підвищити концентрацію препарату в самій пухлині;

- знижується токсична дія хіміопрепарату на організм;

- більш тривала дія препаратів забезпечує довготривалий контакт цитостатика з клітинами пухлини на всіх стадіях клітинного циклу.

Ще одна основна деталь лікування - після введення цитостатика обов'язково слід ввести спеціальні емболи (мікросфери), щоб заблокувати виведення хіміопрепарату [7]. 
Рисунок 1 МСКТ ОГК до операції

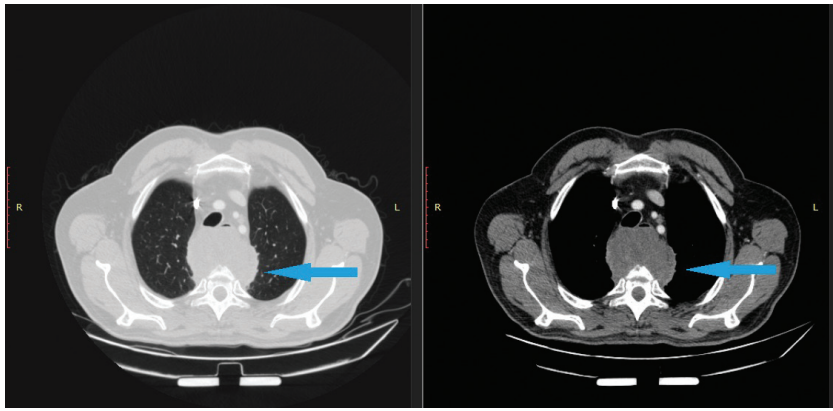

Рисунок 2 МСКТ ОГК до операції: фронтальна проєкція

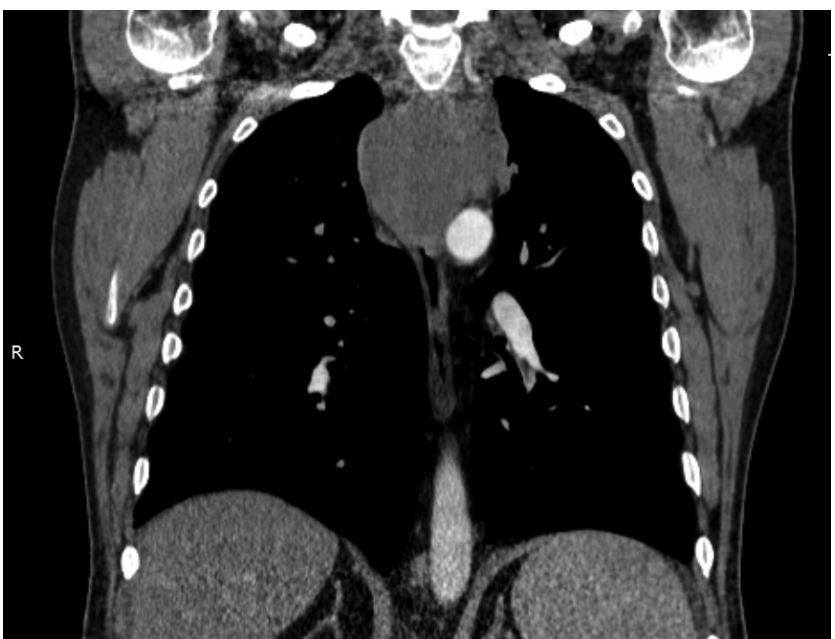

Рисунок 3 МСКТ ОГК до операції: сагітальна проєкція

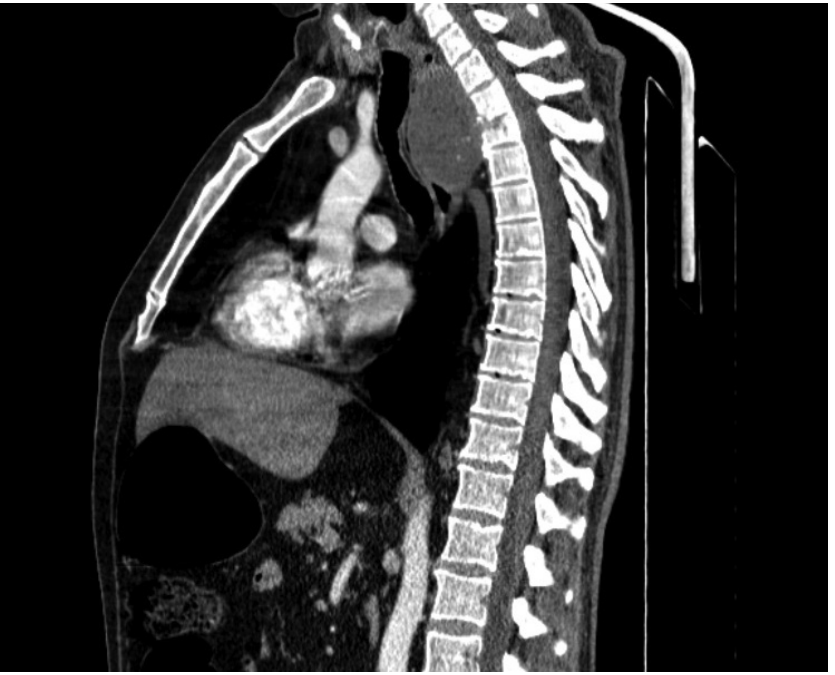

Рисунок 4 МСКТ ОГК після операції

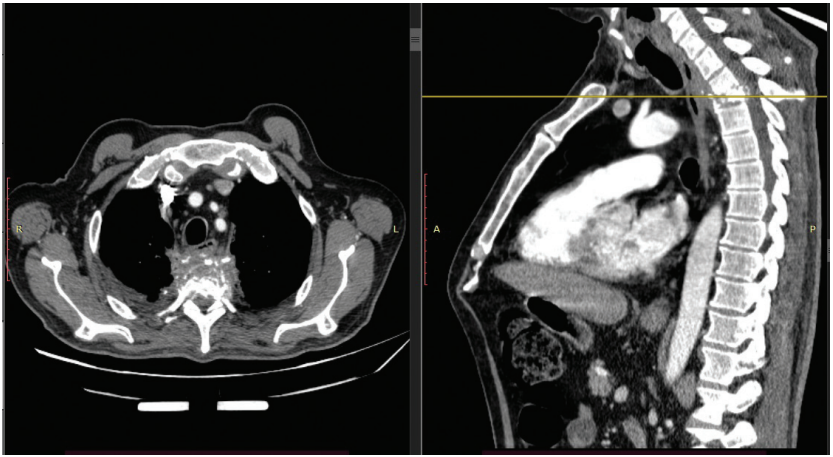

\section{Клінічний випадок}

Пацієнт М., 53 роки. Поступив у хірургічне торакальне відділення КНП «Чернігівська обласна лікарня» Чернігівської обласної ради зі скаргами на загальну слабкість, помірний біль у грудях, субфебрильну температуру тіла.

\section{Анамнез захворювання}

За словами хворого та медичної документації, захворів з кінця січня 2021 р. $з$ підвищенням температури тіла до $39,0^{\circ} \mathrm{C}$. Звернувся за медичною допомогою за місцем проживання. Лікувався у КНП «Ніжинська центральна районна лікарня» 3 приводу абсцесу тильної поверхні правої стопи. Виконано розкриття та дренування абсцесу. Під час лікування виконано комп'ютерну томографію ОГК, діагностовано об'ємне утворення середостіння. Направлений на консультацію у КНП «Чернігівська обласна лікарня» Чернігівської обласної ради. Консультований торакальним хірургом. Госпіталізований у хірургічне торакальне відділення для подальшого обстеження та лікування.

\section{Анамнез життя}

Туберкульоз, тиф, паратиф, малярію, вірусний гепатит заперечує. Алергологічний анамнез не обтяжений. Травм, операцій не було. В анамнезі цукровий діабет 2-го типу, інсулінозалежний. Не застрахований.

\section{Виконані обстеження}

Інструментальні:

1. ФЕС, заключення: «Компресійна деформація середньої $1 / 3$ стравоходу. Помірний дуоденогастральний рефлюкс. Еритематозна гастропатія. Виразка у препілоричному відділі шлунка, гостра фаза. Еритематозна дуоденопатія. Дискінезія дванадцятипалої кишки».

2. МСКТ ОГК, органів черевної порожнини та малого таза проведена 3 внутрішньовенним контрастуванням (Ультравіст 370, 100 мл) (рис. 1-3), заключення: «КТ-ознаки пухлини заднього середостіння (з найбільшою вірогідністю виходить зі стравоходу), що супроводжується деструкцією $\mathrm{Th}_{2-3}$-хребців з наявністю патологічного перелому $\mathrm{Th}_{3}$-хребця. КТ-ознаки одиничних дрібновогнищевих змін легень, гідроперикарда, кальцинозу плеври зліва, гепатоспленомегалії, жирового гепатозу, синусової кисти правої нирки, аномальної кількості ниркових судин у вигляді додаткової ниркової артерії зліва. Враховуючи анамнез, не можна виключити наявність патологічних переломів VII та VIII ребра справа при вторинному ураженні».

3. Допплерехокардіографія, заключення: «Аортосклероз. Дегенеративні зміни стулок аортального клапана. Помірна дилатація лівого передсердя. Гіпертрофія базальних відділів міжшлуночкової перегородки. Діастолічна дисфункція лівого шлуночка за типом порушення релаксації. Скоротлива функція міокарда лівого шлуночка збережена, але відмічається відносний гіпокінез передньої стінки лівого шлуночка».

Обстеження виконано до розкриття абсцесу стопи.

При нормальних показниках червоної крові відмічено помірний лейкоцитоз, підвищену швидкість осідання еритроцитів до 70 мм/год. Гіперглікемія до 30 ммоль/л, ацетон у сечі ${ }^{+++}$.

Після проведеної детоксикаційної, знеболювальної, антибактеріальної терапії, корекції інсулінотерапії хворого переведено з декомпенсованого стану в субкомпенсований, але інтенсивність болю в грудному відділі хребта наростала. Хворий готувався до проведення регіонарної внутрішньоартеріальної хіміоемболізації з подальшою системною хіміотерапією.

Хірургічний консиліум вирішив провести діагностичну відеоторакоскопію для взяття матеріалу для верифікації діагнозу.

Діагноз до операції: «Новоутворення заднього середостіння».

Хворий доставлений в операційну. Проведена операція: відеоторакоскопія справа. Розкриття та дренування абсцесу середнього та заднього середостіння. Біопсія.

Після операції стан хворого покращився. Показники глікемії нормалізувалися.

Рентгенограма ОГК після операції, заключення: «Тінь функціонуючих дренажів. Стан після оперативного втручання. По- 
рівнюючи зі знімком до операції, динаміка позитивна за рахунок зменшення ділянки затінення, що знаходиться проєкційно в нижній частці правої легені. Легеневий малюнок справа посилений за рахунок судинного компонента. Корені легень неструктурні. Синуси: справа візуалізується, зліва - поза кадром. Тінь верхнього середостіння розширена. Серце - розширене за рахунок лівих відділів».

ФЕС після операції, заключення: «Стравохід прохідний. Слизова оболонка дифузно гіперемована, набрякла. Компресія, визначена попередньо, відсутня. Рефлюкс-езофагіт. Пептична виразка кардії шлунка. Ознаки ковзної кили стравохідного отвору діафрагми. Ерозивна гастропатія. Виразка антрального відділу шлунка, підгостра фаза. Застійна дуоденопатія».

Бактеріоскопічне дослідження вмісту абсцесу середнього та заднього середостіння: КСП*-негативний.

МСКТ ОГК з внутрішньовенним контрастуванням після операції (рис. 4), заключення: «У порівнянні з даними КТ-дослідження при попередніх обстеженнях відзначається зменшення розмірів основного процесу в задньому середостінні, але при цьому підвищення ступеня деструкції Th,-хребця і його висоти в передніх і центральних відділах, поява рідини в правій плевральній порожнині, збільшення розмірів внутрішньогрудних лімфатичних вузлів і ступеня накопичення ними контрастної речовини, збільшення розмірів вогнища у $\mathrm{S}_{10}$ правої легені, зменшення кількості рідини в порожнині перикарда, в іншому - без суттєвої динаміки».

Патогістологічне дослідження, заключення: «1. Фрагменти сполучної, жирової та м'язової тканини з хронічним неспецифічним запальним процесом, ділянками гнійного запалення з некрозом, розвитком грануляційної тканини, вогнищевим склерозом, гіалінозом. 2. Сполучна тканина з хронічним неспецифічним запальним процесом, вираженим склерозом, гіалінозом, вогнищеві скупчення ксантомних клітин, ділянки гнійного запалення 3 некрозом та розвитком грануляційної тканини».

Зібраний лікарський консиліум для встановлення діагнозу та подальших рекомендацій.

Основний діагноз: «Цукровий діабет 2-го типу, інсулінозалежний, тяжка форма, декомпенсований стан».

Ускладнення основного діагнозу: «Діабетична мікроангіопатія судин нижніх кінцівок. Остеоартропатія. Діабетична нейропатія. Діабетична стопа справа, змішана форма. Гранулююча рана тилу стопи після розкриття абсцесу. Септичний стан. Абсцес середнього та заднього середостіння. Спондиліт із деструкцією $\mathrm{Th}_{2-3}$-хребців. Реактивний ерозивно-виразковий езофагіт. Інтоксикація».

Супутній діагноз: «Виразка шлунка».

Хворий виписаний із поліпшенням. Надані рекомендації.

\section{Висновок}

Пухлини середостіння - рідкісна патологія, складність виявлення якої обумовлена відсутністю специфічних симп-

\section{Відомості про автора:}

Кравченко Роман Юрійович — лікар-хірург торакальний хірургічного торакального відділення Комунального некомерційного підприємства «Чернігівська обласна лікарня» Чернігівської обласної ради, Чернігів, Україна.

\section{Адреса для кореспонденції:}

Кравченко Роман Юрійович

14001, м. Чернігів, вул. Попова 31а, кв. 68

E-mail: romankrava1985@ukr.net томів і можливістю тривалого безсимптомного перебігу. Хiрургічне лікування відіграє важливу роль у лікуванні та правильній діагностиці новоутворень середостіння, особливо злоякісних. Використання мініінвазивних методів діагностики (відеоторакоскопія, трансторакальна голкова біопсія) дозволяє отримати морфологічну верифікацію при підготовці до лікування та обрати найбільш безпечний і оптимальний вид лікування.

\section{Список використаної літератури/References:}

1. Grandhomme F. (1900) Über Tumoren des vorderen Mediastinums und ihre Beziehungen zu der Thymusdrüse. Heidelberg, Inaug. Diss.

2. NCCN (2019) NCCN Guidelines. Version 1.2020. Thymomas and Thymic Carcinomas (https:// www2.tri-kobe.org/ncen/guideline/lung/english/thymic.pdf).

3. Ganul A.V. (2009) Optimization of diagnosis and treatment of patients with malignant mediastinal tumors. Oncology, 11(2): 131-135. (In Rus.).

4. Masaoka A., Monden Y., Nakahara K., Tanioka T. (1981) Follow-up study of thymomas with special reference to their clinical stages. Cancer, 48(11): 2485-2492. doi: 10.1002/1097-0142(19811201)48:11<2485::aid-cncr2820481123>3.0.c0;2-r.

5. Masaoka A. (2001) Extended transsternal thymectomy for myasthenia gravis. Chest Surg. Clin. N. Am., 2: 369-387.

6. Vetshev P.S., Zaratyants 0.V., Zhivotov V.A. (2004) Thymus gland. In: A.P. Kalinin, N.A. Maistrenko, P.S. Vetshev. Surgical endocrinology: a guide. Peter, Saint Petersburg, 347-462 p. (In Rus.).

7. Borisyuk B.0. (2009) Intra-arterial regional polychemotherapy in the complex treatment of malignant neoplasms of the mediastinum. Oncology, 11(2): 136-138. (In Rus.).

\section{Neoplasm of the mediastinum. Errors in diagnosis and their solution}

\section{R.Yu. Kravchenko}

Communal non-profit enterprise «Chernihiv Regional Hospital» of the Chernihiv Regional Council, Chernihiv, Ukraine

Abstract. Mediastinal tumors are a rare pathology, the difficulty of detection of which is due to the lack of specific symptoms and the possibility of long-term asymptomatic course. The article presents the clinical picture, diagnosis, classification and approaches to treatment of epithelial tumors of the thymus. It is noted that surgical treatment plays an important role in the treatment and proper diagnosis of mediastinal tumors, especially malignant. The use of minimally invasive diagnostic methods (videothoracoscopy, transthoracic needle biopsy) allows to obtain morphological verification in preparation for treatment and to choose the safest and optimal type of treatment. The advantages of intra-arterial administration of chemotherapeutics are described. A clinical case of examination and treatment of a severe patient with posterior mediastinal tumor and concomitant pathology is given.

Key words: thymic tumors, thymic epithelial tumors, thymoma, thymic carcinoma.

\section{Information about the author:}

Kravchenko Roman Yu. - Thoracic Surgeon of the Thoracic Surgical Department of the Communal non-profit enterprise «Chernihiv Regional Hospital» of the Chernihiv Regional Council, Chernihiv, Ukraine.

Address for correspondence:

Roman Kravchenko

14001, Chernihiv, Popov st. 31a, apt. 68

Email: romankrava1985@ukr.net 